\title{
Angiotensin-converting enzyme inhibitory activity in Mexican Fresco cheese
}

\author{
M. J. Torres-Llanez, ${ }^{\star}$ A. F. González-Córdova, ${ }^{*}$ A. Hernandez-Mendoza, ${ }^{*}$ H. S. Garcia,† \\ and B. Vallejo-Cordoba*1 \\ *Laboratorio de Química y Biotecnología de Productos Lácteos Centro de Investigación en Alimentación y Desarrollo A.C. (CIAD), \\ Carretera a La Victoria Km. 0.6, Hermosillo, Sonora 83304, Mexico \\ †Unidad de Investigación y Desarrollo en Alimentos (UNIDA), Instituto Tecnológico de Veracruz M. A. de Quevedo 2279 , \\ Col. Formando Hogar Veracruz, Veracruz 91897, Mexico
}

\section{ABSTRACT}

The objective of this study was to evaluate if Mexican Fresco cheese manufactured with specific lactic acid bacteria (LAB) presented angiotensin I-converting enzyme inhibitory (ACEI) activity. Water-soluble extracts $(3 \mathrm{kDa})$ obtained from Mexican Fresco cheese prepared with specific LAB (Lactococcus, Lactobacillus, Enterococcus, and mixtures: Lactococcus-Lactobacillus and Lactococcus-Enterococcus) were evaluated for ACEI activity. Specific peptide fractions with high ACEI were analyzed using reverse phase-HPLC coupled to mass spectrometry for determination of amino acid sequence. Cheese containing Enterococcus faecium or a Lactococcus lactis ssp. lactis-Enterococcus faecium mixture showed the largest number of fractions with ACEI activity and the lowest half-maximal inhibitory concentration $\left(\mathrm{IC}_{50} ;<10 \mu \mathrm{g} / \mathrm{mL}\right)$. Various ACEI peptides derived from $\beta$-casein $[(\mathrm{f}(193-205), \mathrm{f}(193-207)$, and $\mathrm{f}(193-209)]$ and $\alpha_{\mathrm{S} 1}$-casein $[\mathrm{f}(1-15), \mathrm{f}(1-22), \mathrm{f}(14-23)$, and $\mathrm{f}(24-34)$ ] were found. The Mexican Fresco cheese manufactured with specific LAB strains produced peptides with potential antihypertensive activity.

Key words: bioactive peptide, lactic acid bacteria, Mexican Fresco cheese

\section{INTRODUCTION}

Hypertension is a worldwide risk factor for cardiovascular disease and stroke (Whitworth, 2005). It is now accepted that peptides released by enzymatic hydrolysis of food proteins may exhibit antihypertensive activity by inhibiting the angiotensin-converting enzyme (ACE; FitzGerald and Meisel, 2000; Seppo et al., 2003). Angiotensin-converting enzyme (peptidyldipeptide hydrolase, EC 3.4.15.1) is an exopeptidase that cleaves dipeptides from the C-terminal side of various oligopeptides. As part of the renin-angiotensin system,

Received February 4, 2011.

Accepted April 15, 2011.

${ }^{1}$ Corresponding author: vallejo@ciad.mx
ACE hydrolyses angiotensin I, an inactive decapeptide, to the potent vasoconstrictor angiotensin II. It also inactivates the vasodilator bradykinin, which is involved in blood pressure control (Korhonen and Pihlanto, 2006; Lopez-Fandiño et al., 2006). Remarkable efforts have been made in the production of natural foods for the promotion of a healthier lifestyle, with emphasis in the role played by the diet in disease prevention and treatment. These components include food-derived bioactive peptides and, more specifically, peptides with ACE inhibitory (ACEI) activity. Among them, milk proteins are identified as one of the most important sources of ACE inhibitors.

Cheese is an important dairy product containing numerous peptides released by proteolysis during the ripening period. The profile of these peptides differs depending on the variety of cheese and ripening time (Gómez-Ruiz et al., 2006). These peptides participate in the flavor and texture of cheese (Gómez-Ruiz et al., 2007), but some of them have also revealed ACEI activity (Saito et al., 2000; Silva et al., 2006; Bütikofer et al., 2008). However, those studies were conducted with ripened cheeses. To the best of our knowledge, the ACEI activity of unripened cheeses such as Mexican Fresco cheese has not been reported.

Mexican Fresco cheese is characterized by being high in moisture content, having a mild milky flavor, a soft and creamy texture, and a very short shelf-life (Van Hekken and Farkye, 2003; Torres-Llanez et al., 2006). This type of cheese has a moisture content of $63.4 \pm$ $3.8 \%$, a protein content of $15.63 \pm 1.35 \%$, a fat content of $15 \pm 3.16 \%$, and a pH of $6.0 \pm 0.2$ (Torres-Llanez et al., 2006). This rennet-set cheese is the most popular cheese consumed in Mexico and is a preferred choice of Mexican residents in the United States. Consequently, it would be valuable to know if this type of cheese presented ACEI activity so that it could potentially offer an additional food value. Thus, the aim of this study was to evaluate if Mexican Fresco cheese made with specific lactic acid bacteria (LAB) presented ACEI activity and to find and characterize peptides with ACEI activity. 


\section{MATERIALS AND METHODS}

\section{LAB Strains and Culture Propagation}

Strains of LAB used in the manufacture of Mexican Fresco cheese were obtained from the Dairy Laboratory collection at Centro de Investigación en Alimentación y Desarrollo (CIAD, Hermosillo, Sonora, Mexico). Cultures consisted of 3 strains: Lactococcus lactis ssp. lactis, Enterococcus faecium, and Lactobacillus casei, which were isolated from raw milk Mexican Fresco cheese (Torres-Llanez et al., 2006). The strains were activated by growing them at $37^{\circ} \mathrm{C}$ overnight in $10 \%$ (wt/vol) sterile reconstituted skim milk. Then, the strains were propagated for $18 \mathrm{~h}$ at $37^{\circ} \mathrm{C}$ in reconstituted skim milk until they reached the required number for inoculation $\left(10^{8} \mathrm{cfu} / \mathrm{mL}\right)$ into cheese milk.

\section{Cheesemaking Procedures}

Two batches of raw milk (60 L) collected on 2 occasions from a local dairy farm were used for cheese manufacture. Milk was pasteurized at $65^{\circ} \mathrm{C}$ for 30 min, and then set at $34^{\circ} \mathrm{C}$ for culture inoculation. Five cheeses were manufactured with different LAB cultures (Lc. lactis ssp. lactis, E. faecium, Lb. casei, and 1:1 mixtures of Lc. lactis ssp. lactis-Lb. casei and Lc. lactis ssp. lactis-E. faecium) at inoculum levels of $1 \mathrm{~mL} / \mathrm{L}$ for single strains and $0.5 \mathrm{~mL} / \mathrm{L}$ for mixed strains. Additionally, one control cheese was manufactured without added LAB. After a 2-h incubation, $1.5 \mathrm{~mL}$ of commercial calf rennet (strength 1:10,000, Industrias Cuamex, S.A. de C.V., Mexico, D. F., Mexico) was added to each milk batch. Coagulation took place at 32 to $34^{\circ} \mathrm{C}$ for $1 \mathrm{~h}$. Then, the curd was cut until a grain the size of a hazelnut was obtained. At this stage, whey was drained off and salt was added $(3 \%)$ to the curd, which was manually homogenized. Finally, the salted curd was molded and stored overnight under refrigeration $\left(4^{\circ} \mathrm{C}\right)$. Under these procedures, 5 experimental Mexican Fresco cheeses from each milk batch were prepared: $L c$. lactis ssp. lactis (CLl), E. faecium (CEf), Lb. casei (CLc), Lc. lactis ssp. lactis-Lb. casei (CLlLc), and Lc. lactis ssp. lactis-E. faecium (CLlEf). Water-soluble cheese extracts were prepared $5 \mathrm{~d}$ after cheese storage at $4^{\circ} \mathrm{C}$. Sampling at d 5 was selected because this type of cheese is consumed immediately after manufacture and not later than 1 wk after manufacture.

\section{Preparation of Water-Soluble Extracts}

Five-day-old cheese samples (20 g) were homogenized in $40 \mathrm{~mL}$ of deionized water during 5 min using a Stomacher 400 (Colworth, London, UK). The resulting homogenates were held at $4^{\circ} \mathrm{C}$ for $1 \mathrm{~h}$. The insoluble material was then separated by centrifugation at 10,000 $\times g$ for 30 min (model RC5C, Sorval Wilmington, NC) at $4^{\circ} \mathrm{C}$. The supernatants were filtered through glass wool to remove residual suspended fat and freeze-dried.

Lyophilized water-soluble extracts (WSE) were redissolved in deionized water (10\%), filtered with macrosep centrifugal devices (Pall Life Science, Ann Arbor, MI) with a cut-off point of 3,000 Da, and centrifuged at $3,000 \times g$ for $45 \mathrm{~min}$ at $25^{\circ} \mathrm{C}$.

The concentration of protein in WSE was determined by the Bradford method (Bio-Rad Protein Assay; http://www.bio-rad.com/LifeScience/pdf/ Bulletin_9004.pdf; Gobbetti et al., 2000; Donkor et al., 2007). Briefly, $800 \mu \mathrm{L}$ from each reconstituted WSE was placed in a clean and dry test tube; then, $200 \mu \mathrm{L}$ of dye reagent was added to each tube and vortexed. The test tubes were incubated at room temperature $\left(25^{\circ} \mathrm{C}\right)$ for at least $5 \mathrm{~min}$. After that, absorbance was measured at $595 \mathrm{~nm}$. All analyses were performed in duplicate.

\section{WSE Analysis by Reverse Phase HPLC}

Reverse phase (RP)-HPLC was performed by using an Agilent 1100 Series HPLC (Agilent Technologies, Waldbronn, Germany). Reconstituted WSE (20 $\mu \mathrm{L})$ were injected into the reverse-phase column (300 Extend-C18, $4.6 \mathrm{~mm} \times 250 \mathrm{~mm}, 5 \mu \mathrm{m}$; Agilent Technologies, Santa Clara, CA). Separation was conducted at room temperature $\left(\sim 22^{\circ} \mathrm{C}\right)$ at a flow rate of $0.5 \mathrm{~mL} /$ min. Solvent A was a mixture of water:trifluoroacetic acid (1,000:0.1, vol/vol) and solvent B consisted of acetonitrile:trifluoroacetic acid (1,000:0.1, vol/vol). Peptides were eluted by using a linear gradient of solvent $\mathrm{B}$ in $\mathrm{A}$, from 5 to $100 \%$ in $77 \mathrm{~min}$. The concentration of solvent B was linearly increased from 0 to $5 \%$ for $16 \mathrm{~min}$; from 5 to $46 \%$ between 16 and $62 \mathrm{~min}$; and from 46 to $100 \%$ between 62 and $72 \mathrm{~min}$, finally reaching $100 \%$ between 72 and $77 \mathrm{~min}$. Absorbance was recorded at $214 \mathrm{~nm}$.

Sixteen fractions from each WSE were collected using a fraction collector (Agilent 1100 Series, Analytical FC, Waldbronn, Germany). Fractions from several chromatographic runs were pooled and dried using a Centrivap Concentrator (Labconco, Kansas City, MO). Then, fractions were redissolved in $300 \mu \mathrm{L}$ of borate buffer $(100 \mathrm{~m} M, \mathrm{pH}$ 8.3) containing $300 \mathrm{~m} M \mathrm{NaCl}$. Aliquots $(100 \mu \mathrm{L})$ from each fraction were used to determine ACEI activity. Protein content of each fraction was estimated by the Bradford assay as described previously.

\section{Determination of ACEI Activity}

Activity of ACEI was determined following the spectrophotometric assay reported by Nakamura et 
Table 1. Angiotensin-converting enzyme-inhibitory (ACEI) activity and $50 \%$ inhibitory concentration $\left(\mathrm{IC}_{50}\right)$ values of water-soluble extracts obtained from different Mexican Fresco cheeses (mean $\pm \mathrm{SE}$, $\mathrm{n}=3)$

\begin{tabular}{lcc}
\hline Cheese $^{1}$ & $\begin{array}{c}\text { ACEI } \\
(\%)\end{array}$ & $\begin{array}{c}\mathrm{IC}_{50} \\
(\mu \mathrm{g} / \mathrm{mL})\end{array}$ \\
\hline CLl & $95.6 \pm 0.01^{\mathrm{a}}$ & $5.2 \pm 0.10^{\mathrm{a}}$ \\
CLc & $95.5 \pm 0.01^{\mathrm{b}}$ & $5.3 \pm 0.10^{\mathrm{a}}$ \\
CEf & $96.3 \pm 0.01^{\mathrm{c}}$ & $10.4 \pm 0.40^{\mathrm{b}}$ \\
CLlLc & $99.8 \pm 0.01^{\mathrm{d}}$ & $6.8 \pm 0.10^{\mathrm{c}}$ \\
CLlEf & $95.3 \pm 0.01^{\mathrm{e}}$ & $10.7 \pm 0.10^{\mathrm{b}}$ \\
\hline
\end{tabular}

${ }^{\mathrm{a}-\mathrm{e}}$ Values showing the same superscript within a column were not significantly different $(P<0.05)$.

${ }^{1} \mathrm{CLl}=$ cheese containing Lactococcus lactis $\mathrm{ssp}$. lactis; $\mathrm{CLc}=$ cheese containing Lactobacillus casei; $\mathrm{CEf}=$ cheese containing Enterococcus faecium; CLlLc $=$ cheese containing Lc. lactis ssp. lactis-Lb. casei mixture; CLIEf = cheese containing Lc. lactis ssp. lactis-E. faecium mixture.

al., (1995). The method is based on the liberation of hippuric acid from hippuryl-histidyl-leucine catalyzed by ACE. Briefly, samples $(80 \mu \mathrm{L})$ were preincubated at $37^{\circ} \mathrm{C}$ for $3 \mathrm{~min}$ with $200 \mu \mathrm{L}$ of $0.1 \mathrm{M}$ borate buffer (pH 8.3) containing $0.3 \mathrm{M} \mathrm{NaCl}$ and $5 \mathrm{mM}$ hippurylhistidyl-leucine (Sigma Chemical, St. Louis, MO). Afterward, $20 \mu \mathrm{L}$ of $0.1 \mathrm{U} / \mathrm{mL}$ ACE (EC 3.4.15.1, $5 \mathrm{U}$; Sigma) was added and the mixture was incubated at $37^{\circ} \mathrm{C}$ for $30 \mathrm{~min}$. Then, the reaction was stopped with $1 N \mathrm{HCl}(250 \mu \mathrm{L})$ and the hippuric acid was extracted with ethyl acetate $(1,200 \mu \mathrm{L})$. After the proper removal of solvent by vacuum evaporation, the hippuric acid was redissolved in $1,000 \mu \mathrm{L}$ of deionized water and the absorbance of the solution was measured spectrophotometrically at $228 \mathrm{~nm}$. The extent of inhibition was calculated as follows:

$$
\text { ACEI activity }(\%)=[(B-A) /(B-C)] \times 100,
$$

where $A$ is the absorbance in the presence of $\mathrm{ACE}$ and the ACEI component, $B$ is the absorbance without the ACEI component, and $C$ is the absorbance without ACE. Activity of ACEI was expressed in terms of the protein concentration $(\mu \mathrm{g} / \mathrm{mL})$ in the sample required to inhibit $50 \%$ of the ACE activity $\left(\mathbf{I C}_{50}\right)$. Those fractions with the highest ACEI activity were subjected to further identification by liquid chromatography-tandem mass spectrometry (LC-MS/MS).

\section{HPLC/Electrospray lonization MS Analysis}

All MS analyses were performed using an 1100 Series LC/MSD Trap (Agilent Technologies Inc. Waldronn, Germany) equipped with an electrospray ionization source (LC-ESI-MS), and a C18-300SB nano-column $(150 \mathrm{~mm} \times 0.75 \mu \mathrm{m}, 3.5 \mu \mathrm{m}$, Agilent Technologies Inc.). The sample injection volume was $1 \mu \mathrm{L}$. Sol- vent $A$ was a mixture of water:acetonitrile:formic acid (10:90:0.1, vol/vol/vol), and solvent B contained water:acetonitrile:formic acid (97:3:0.1, vol/vol/vol). A flow of $0.7 \mu \mathrm{L} / \mathrm{min}$ was directed into the mass spectrometer via an electrospray interface. The instrument used nitrogen as the nebulizing and drying gas and operated with an estimated helium pressure of $500 \mathrm{~Pa}$. The capillary was held at $4 \mathrm{kV}$. Mass spectra were acquired over a range of 300 to $2,500 \mathrm{~m} / \mathrm{z}$. The maximal capture time was $50 \mathrm{~ms}$ and the signal threshold to perform auto $\mathrm{MS}^{\mathrm{n}}$ analyses was 30,000 . The precursor ions were isolated within a range of $4.0 \mathrm{~m} / z$ and fragmented with a voltage ramp from 0.35 to $1.1 \mathrm{~V}$.

\section{RESULTS AND DISCUSSION}

\section{ACEI Activities of Mexican Fresco Cheeses}

Water-soluble extracts $(<3 \mathrm{kDa})$ obtained from Mexican Fresco cheeses inoculated with LAB showed ACEI activities ranging between 95.3 and $99.8 \%$ and $\mathrm{IC}_{50}$ values ranging between 5.2 and $10.7 \mu \mathrm{g} / \mathrm{mL}$ (Table 1). These results suggested that ACEI activity and $\mathrm{IC}_{50}$ in cheese WSE were dependent on the specific LAB used for cheese manufacture. It has been reported that LAB could generate a large variety of peptides, including bioactive peptides. In fact, ACE inhibitory peptides have been found in several types of aged cheeses, which differed with respect to the type of starter and the ripening conditions used (Saito et al., 2000; Sieber et al., 2009).

The highest ACEI activity corresponded to the WSE from cheese made with the Lc. lactis ssp. lactis-Lb. casei mixture. However, the lowest $\mathrm{IC}_{50}$ was obtained for the WSE from cheese made with Lc. lactis ssp. lactis (Table 1). The potency of an ACE inhibitor is usually expressed as an $\mathrm{IC}_{50}$ value, which is the concentration of inhibitor leading to $50 \%$ inhibition of ACE activity (Heber et al., 2010). Thus, a cheese extract with the lowest $\mathrm{IC}_{50}$ requires a lower concentration of peptide to achieve ACE inhibition. It is interesting to notice that Lc. lactis ssp. lactis was the prevalent species in artisanal Mexican Fresco cheese produced from raw milk (Torres-Llanez et al., 2006). Thus, it would be expected that this type of cheese might have significant ACEI activity.

The release of ACE-inhibitory peptides in Cheddar cheese made with lactococci and probiotic strains of $L b$. casei has been reported (Ong et al., 2007; Ong and Shah, 2008), although their results suggested that ACEI activity was dependent on proteolysis during ripening. On the other hand, ACEI activity in Mexican Fresco cheese determined in this study was detected only $5 \mathrm{~d}$ after manufacture. It has been reported that ACEI ac- 
tivity produced in milk after a 48 -h incubation with $L c$. lactis isolated from different niches is strain-dependent (Rodriguez-Figueroa et al., 2010). In that report, the highest ACEI activities were found in WSE from milk inoculated with wild Lc. lactis strains isolated from artisanal dairy products. In fact, a strain isolated from an artisanal Mexican cheese presented the lowest $\mathrm{IC}_{50}$ $(13 \mu \mathrm{g} / \mathrm{mL})$ of all fermented milks (Rodriguez-Figueroa et al., 2010).

\section{Peptide Isolation and Collection by HPLC}

Semi-preparative RP-HPLC of WSE resulted in 14 to 16 fractions collected for each cheese. The ACEI activity and the corresponding $\mathrm{IC}_{50}$ values for WSE fractions from Mexican Fresco cheese made with Lc. lactis ssp. lactis, Lb. casei, or E. faecium are shown in Figure 1.

From the 14 collected fractions (F1 to F14) of the WSE from cheese made with Lc. lactis ssp. lactis (Figure $1 \mathrm{~A}$ ), only 7 fractions presented ACEI activity. The $\mathrm{IC}_{50}$ values of these fractions were much lower than the $\mathrm{IC}_{50}$ of 500 or $520 \mu \mathrm{g} / \mathrm{mL}$ obtained for milk fermented by Lc. lactis ssp. lactis (Pihlanto et al., 2010) or Lc. lactis ssp. cremoris (Muguerza et al., 2006), respectively. In fact, fractions $\mathrm{F} 1, \mathrm{~F} 11$, and $\mathrm{F} 12$ presented $\mathrm{IC}_{50}$ values $<10 \mu \mathrm{g} / \mathrm{mL}$ (Figure 1A).

From the 14 collected fractions (F1 to F14) of the WSE from cheese made with $L b$. casei (Figure 1B), only 8 fractions presented ACEI activity. In this case, all fractions except $\mathrm{F} 3, \mathrm{~F} 7$, and $\mathrm{F} 10$ presented $\mathrm{IC}_{50}$ values $<10 \mu \mathrm{g} / \mathrm{mL}$. The inclusion of $L b$. casei as a probiotic adjunct in Cheddar cheeses resulted in WSE with increased ACEI activity, with $\mathrm{IC}_{50}$ ranging from 0.1 to $2.0 \mathrm{mg} / \mathrm{mL}$ (Ong et al., 2007). However, the $L b$. casei strain used in the present study appeared to have a more pronounced $\mathrm{ACE}$ inhibition because $\mathrm{IC}_{50}$ values for the different fractions (Figure 1B) and the WSE extract $(5.3 \pm 0.1$, Table 1$)$ were much lower than $\mathrm{IC}_{50}$ values reported for Cheddar cheeses (Ong et al., 2007).

From the 15 collected fractions (F1 to F15) of the WSE from cheese made with E. faecium (Figure 1C), $\mathrm{F} 1$ to $\mathrm{F} 12$ showed $\mathrm{ACEI}$ activity and $\mathrm{IC}_{50}$ values $<6$ $\mu \mathrm{g} / \mathrm{mL}$ (Figure 1C). In particular, F3 exhibited an $\mathrm{IC}_{50}$ value of $2.6 \mu \mathrm{g} / \mathrm{mL}$ (Figure $1 \mathrm{C}$ ). Similar $\mathrm{IC}_{50}$ values were reported for fractions produced by proteases from Cynara cardunculus in cheese-like systems (Silva et al., 2006 ), although the $\mathrm{IC}_{50}$ values obtained in the present study were much lower than the $\mathrm{IC}_{50}$ values of 34 to 59 $\mu \mathrm{g} / \mathrm{mL}$ obtained for milk fermented by $E$. faecalis (Muguerza et al., 2006; Quirós et al., 2007). Interestingly, E. faecalis has been detected in artisanal Mexican Fresco cheese manufactured from raw milk (Torres-Llanez et al., 2006) and was further confirmed by others (Renye et al., 2008).
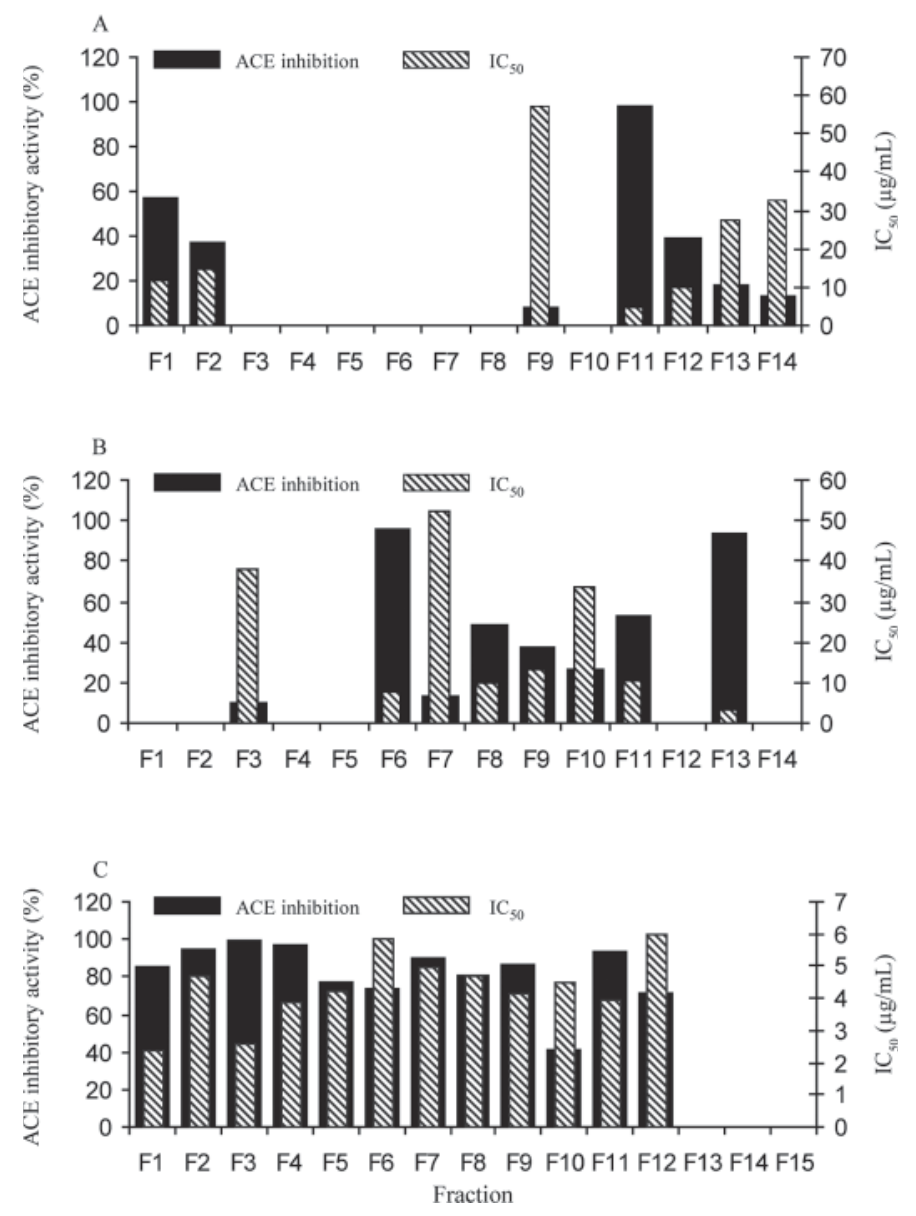

Figure 1. Angiotensin-converting enzyme (ACE) inhibitory activity and $\mathrm{IC}_{50}$ values of fractions collected from water-soluble extracts (WSE) from Mexican Fresco cheese manufactured with specific lactic acid bacteria $(\mathrm{n}=2)$ : (A) Lactococcus lactis ssp. lactis, (B) Lactobacillus casei, and (C) Enterococcus faecium.

The ACEI activity and their corresponding $\mathrm{IC}_{50}$ values presented in WSE from Mexican Fresco cheese made with the Lc. lactis ssp. lactis-Lb. casei mixture are shown in Figure 2A. Although only 5 fractions showed ACEI activity, $\mathrm{IC}_{50}$ values were all $<10 \mu \mathrm{g} /$ $\mathrm{mL}$ (Figure 2A). On the other hand, cheese made with the Lc. lactis ssp. lactis-E. faecium mixture presented a larger number of fractions (13) with ACEI activity and $\mathrm{IC}_{50}$ values $<10 \mu \mathrm{g} / \mathrm{mL}$, except for F3 (Figure $2 \mathrm{~B}$ ).

From these results, it appears that Mexican Fresco cheese manufactured from milk inoculated with $E$. faecium or Lc. lactis ssp. lactis-E. faecium mixture showed the largest number of fractions (12) with ACEI activity and low $\mathrm{IC}_{50}$ values $(<10 \mu \mathrm{g} / \mathrm{mL})$. The composition of the $\mathrm{LAB}$ proteolytic system is thought to influence $\mathrm{ACE}$ inhibition; in fact, negative mutants for peptidase activities presented higher ACEI activities than their wildtype counterparts (Algaron et al., 2004). Thus, differences among ACEI activities from WSE of cheeses made with 

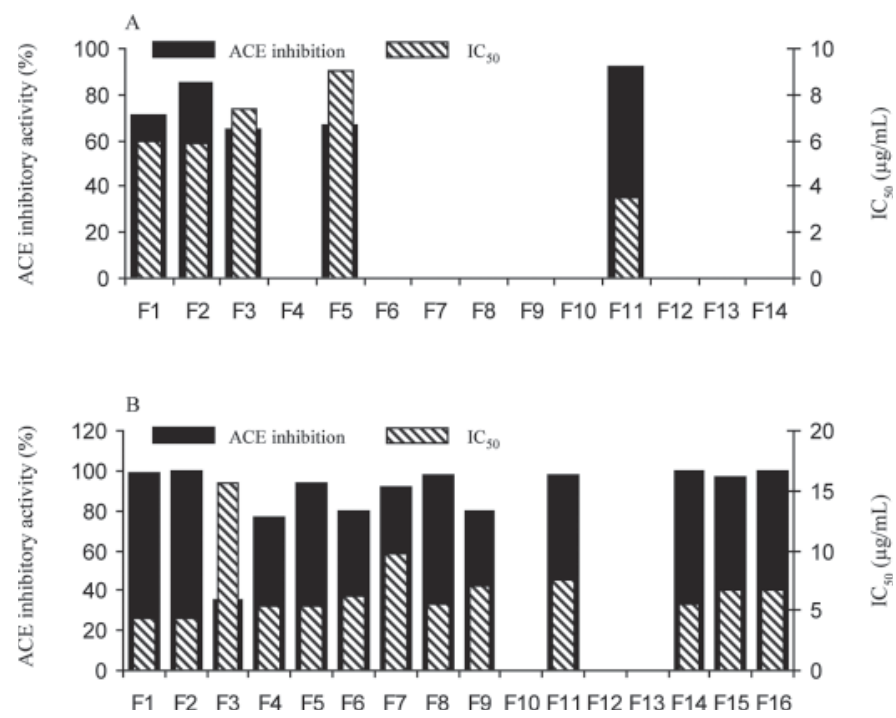

Figure 2. Angiotensin-converting enzyme (ACE) inhibitory activity and $\mathrm{IC}_{50}$ values of fractions collected from water-soluble extracts (WSE) from Mexican Fresco cheese manufactured with specific lactic acid bacteria ( $\mathrm{n}=2$ ): (A) Lactococcus lactis ssp. lactis-Lactobacillus casei; (B) Lc. lactis ssp. lactis-Enterococcus faecium.

specific LAB may be due to differences in the proteinases and peptidases of the specific LAB present.

Thus, addition of these specific LAB strains to milk for Fresco cheese manufacture may be a good alternative for increasing ACE inhibition and could add value to this type of traditional Mexican cheese. Indeed, $E$. faecium and Lc. lactis were the most abundant LAB species detected in Mexican Fresco cheese manufactured from raw milk (Torres-Llanez et al., 2006).

\section{Identification of Peptides by LC-ESI-MSIMS}

Even though, the initial number of collected fractions was very high (73 fractions), many fractions did not produce an adequate signal for MS detection. Therefore, only 4 fractions from cheese made with E. faecium and 1 fraction from cheese made with $L b$. casei were further analyzed by LC-ESI-MS/MS. A typical mass spectrum for one of the fractions (F10) from cheese made with $E$. faecium showing double-charge ions, 941.7 and 729.9, is depicted in Figures 3A and 3B. The tandem mass spectrum of these 2 double-charge ions and the amino acid sequences of these peptides are shown in Figure $3 \mathrm{C}$ and 3D. Fraction F10 contained 2 peptides with YQEPVLGPVRGPF (f193-205) and YQEPVLGPVRGPFPIIV (f193-209) sequences from $\beta$-CN.

Observed and calculated masses, molecular ions $(m / z)$, protein fragments, and amino acid sequences for the identified peptides are shown in Table 2. Peptide sequences in Mexican Fresco cheese made with $E$. faecium or $L b$. casei were identified as $\alpha_{\mathrm{S}^{-}}$and $\beta-\mathrm{CN}$ fragments and their size varied from 10 to 22 amino acid residues. Peptides $(<3 \mathrm{kDa})$ belonging to $\kappa$-casein were not identified in any of the cheeses. The high proteolysis resistance of para- $\kappa-\mathrm{CN}$ in cheese may explain this finding (Swaisgood, 2003).

In this study, 4 peptides were identified as deriving from the N-terminal portion of $\alpha_{\mathrm{S}^{-}} \mathrm{CN}$ and 3 peptides as deriving from the $\mathrm{C}$-terminal of $\beta$-CN (Table 2). All identified peptides in this study had a strong hydrophobic character and all except one were rich in the amino acid proline. In addition, these peptides contained arginine and lysine in the C-terminal portion. According to the literature, this portion corresponded to the hydrophobic portion of $\alpha_{\mathrm{S}^{-}}$and $\beta$-CN (Swaisgood, 2003). Activity of ACEI is strongly influenced by the C-terminal tripeptide sequence in the substrate; competitive inhibitors or substrates containing hydrophobic (aromatic or branched side chains) amino acid residues at each of the C-terminal positions appear to be preferred by ACE (Lopez-Fandiño et al., 2006). Another characteristic of these bioactive peptides is the presence of the positive charge on the guanidine and the $\varepsilon$-amino group of the C-terminal in arginine and the lysine side chain, respectively, which contribute substantially to the potency of inhibition (Gobbetti et al., 2004; LopezFandiño et al., 2006). Additionally, the presence of proline in the C-terminal sequence contributes to the correct location of the peptide in the active site of the enzyme, probably because of the rigid structure of this residue (Cushman et al., 1977).

Various peptides with ACEI activity that originated from the N-terminal portions of $\alpha_{\mathrm{S1}^{-}} \mathrm{CN}$ were also reported in aged cheeses such as Gouda (Saito et al., 2000) and Cheddar cheese (Ong et al., 2007) or in cheese-like systems prepared with proteases from Cynara cardunculus (Silva et al., 2006). Moreover, a peptide from the C-terminal portion of $\beta$-CN with ACEI activity, YQEPVLGPVRGPFPIIV (f193-209), was reported in Manchego cheese (Gómez-Ruiz et al., 2002). Other studies also reported this peptide in Cheddar cheese (Ong et al., 2007); moreover, this peptide was likely the hydrolysis product of chymosin and cell wall-associated proteinases from starter lactococci or from probiotic adjuncts (Ong et al., 2007). On the contrary, peptide EVLNENLLRF $\left(\alpha_{\mathrm{S}_{1}} \mathrm{CN}, \mathrm{f} 14-23\right)$ found in the present study was not reported in previous studies. Proteinases of LAB can hydrolyze more than $40 \%$ of the peptide bonds of $\alpha_{\mathrm{S} 1}$-and $\beta$-CN, resulting in the formation of more than 100 different oligopeptides, which are in turn actively degraded by the complex peptidase system (Ong et al., 2007). Consequently, different LAB could generate a wide variety of peptides. 
Table 2. Molecular mass determination and peptide identification in fractions collected from water-soluble extracts from Mexican Fresco cheeses inoculated with specific lactic acid bacteria

\begin{tabular}{|c|c|c|c|c|c|}
\hline Fraction $^{1}$ & $\begin{array}{l}\text { Observed } \\
\text { mass }\end{array}$ & $\begin{array}{l}\text { Calculated } \\
\text { mass }\end{array}$ & $\begin{array}{c}\text { Molecular ion }(m / z) \\
\text { selected for } \\
\text { MS/MS (charge) }\end{array}$ & $\begin{array}{l}\text { Protein } \\
\text { sequence }^{2}\end{array}$ & $\begin{array}{l}\text { AA } \\
\text { sequence }\end{array}$ \\
\hline F8 (Lc) & $\begin{array}{l}1,668.04 \\
1,880.28 \\
1,236.82 \\
1,245.86\end{array}$ & $\begin{array}{l}1,667.90 \\
1,880.05 \\
1,236.65 \\
1,245.67\end{array}$ & $\begin{array}{l}835.0(+2) \\
941.4(+2) \\
619.4(+2) \\
624.0(+2)\end{array}$ & $\begin{array}{l}\beta-\mathrm{CN}(\mathrm{f} 193-207) \\
\beta-\mathrm{CN}(\mathrm{f} 193-209) \\
\alpha_{\mathrm{S} 1}-\mathrm{CN}(\mathrm{f} 24-34) \\
\alpha_{\mathrm{S} 1}-\mathrm{CN}(\mathrm{f} 14-23)\end{array}$ & $\begin{array}{l}\text { YQEPVLGPVRGPFPI } \\
\text { YQEPVLGPVRGPFPIIV } \\
\text { FVAPFPEVFGK } \\
\text { EVLNENLLRF }\end{array}$ \\
\hline F6 (Ef) & $1,893.38$ & $1,892.04$ & $945.2(+2)$ & $\alpha_{\mathrm{S} 1^{-}} \mathrm{CN}(\mathrm{f} 1-15)$ & RPKHPIKHQGLPQEV \\
\hline F9 (Ef) & $\begin{array}{l}2,763.87 \\
1,236.90 \\
1,246.22\end{array}$ & $\begin{array}{l}2,762.54 \\
1,236.65 \\
1,245.67\end{array}$ & $\begin{array}{l}922.3(+3) \\
619.5(+2) \\
624.2(+2)\end{array}$ & $\begin{array}{l}\alpha_{\mathrm{S1}_{1}} \mathrm{CN}(\mathrm{f} 1-22) \\
\alpha_{\mathrm{S}_{1}} \mathrm{CN}(\mathrm{f} 24-34) \\
\alpha_{\mathrm{S1}}-\mathrm{CN}(\mathrm{f} 14-23)\end{array}$ & $\begin{array}{l}\text { RPKHPIKHQGLPQEVLNENLLR } \\
\text { FVAPFPEVFGK } \\
\text { EVLNENLLRF }\end{array}$ \\
\hline F10 (Ef) & $\begin{array}{l}1,457.80 \\
1,881.46\end{array}$ & $\begin{array}{l}1,457.76 \\
1,880.05\end{array}$ & $\begin{array}{l}729.9(+2) \\
941.7(+2)\end{array}$ & $\begin{array}{l}\beta-\mathrm{CN}(\mathrm{f} 193-205) \\
\beta-\mathrm{CN}(\mathrm{f} 193-209)\end{array}$ & $\begin{array}{l}\text { YQEPVLGPVRGPF } \\
\text { YQEPVLGPVRGPFPIIV }\end{array}$ \\
\hline
\end{tabular}

${ }^{1} \mathrm{Lc}=$ Lactobacillus casei $; \mathrm{Ef}=$ Enterococcus faecium.

${ }^{2}$ Protein sequence according to Swaisgood (2003).

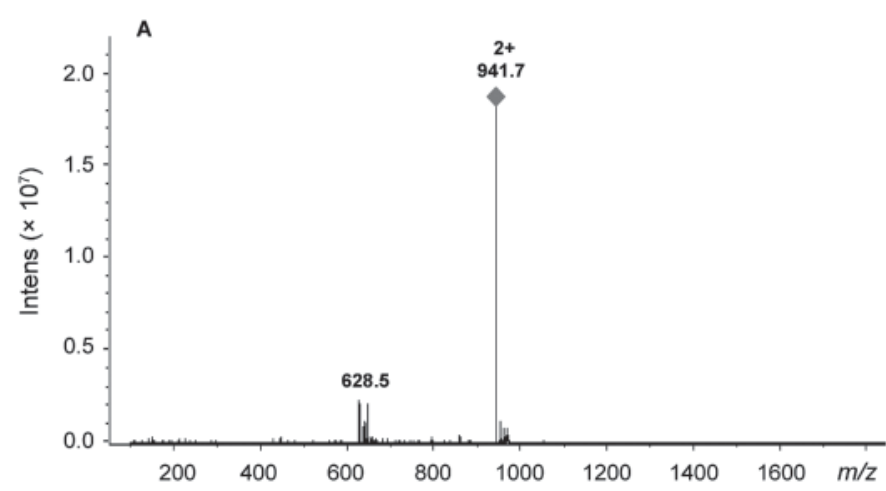

$y$ ions
$\mathrm{b}$ ions
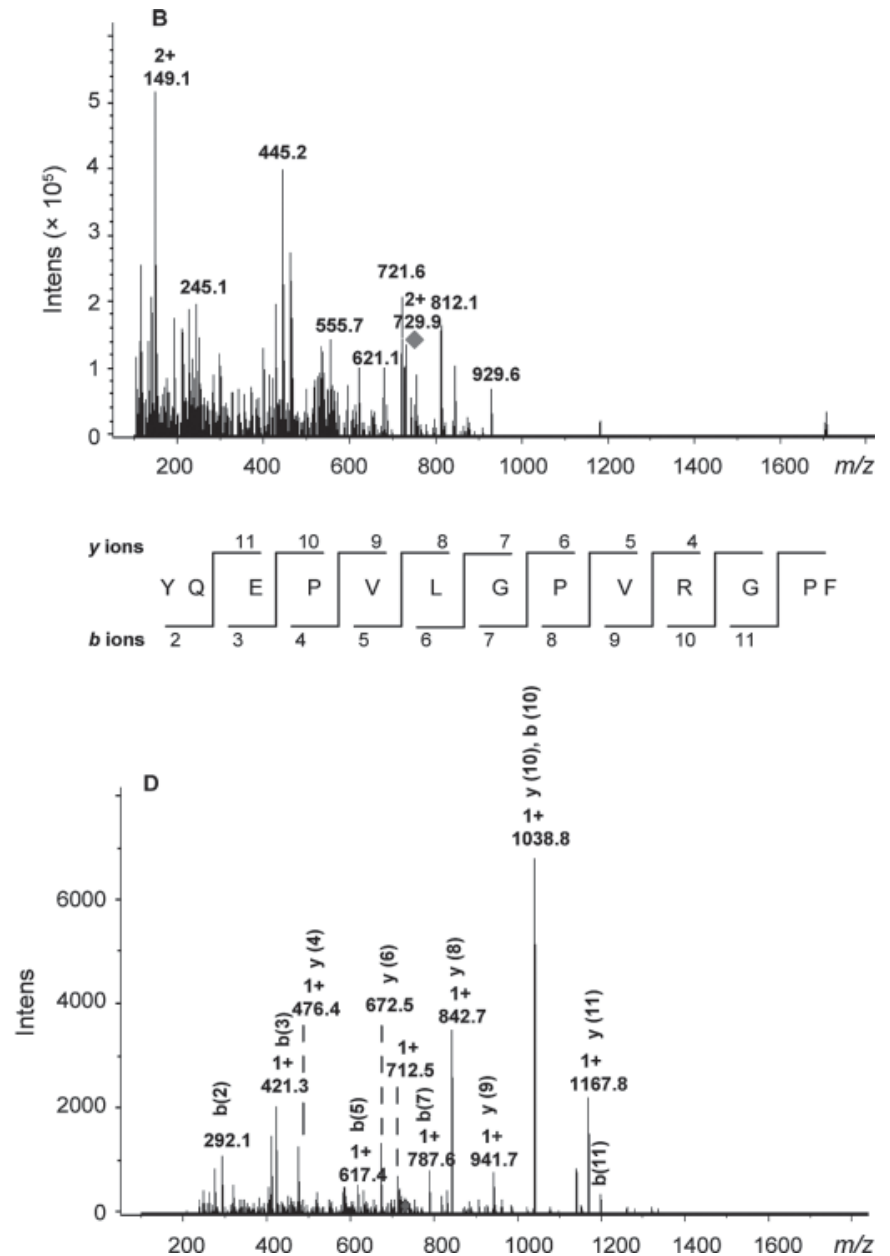

Figure 3. Typical mass spectra for fraction F10 collected from the water-soluble extract from cheese made with Enterococcus faecium: (A) double-charge ion $m / z$ 941.7; (B) double-charge ion $m / z 729.9$; (C) MS/MS spectrum for $m / z 941.7$ and fragment amino acid sequence [ $\beta$-CN (f193-209)]; (D) MS/MS spectrum for $m / z 729.9$ and fragment amino acid sequence [ $\beta-C N$ (f193-205)]. 


\section{CONCLUSIONS}

Although Mexican Fresco cheese is unripened, the addition of specific strains of LAB during cheese manufacture resulted in the production of ACE inhibitors. From the cheeses studied, those containing E. faecium or a Lc. lactis ssp. lactis-E. faecium mixture produced the most peptide fractions with ACEI activity. Thus, Mexican Fresco cheese manufactured with specific LAB strains produced peptides with potential health benefits; these benefits need to be tested by conducting in vivo studies.

\section{ACKNOWLEDGMENTS}

This study was supported by the Mexican National Council of Science and Technology (CONACyT) research grants (CB-2006-1-62543 and CB-2009-1134295).

\section{REFERENCES}

Algaron, F., D. Miranda, and V. Monnet. 2004. Milk fermentation by Lactococcus lactis with modified proteolytic systems to accumulate potentially bio-active peptides. Lait $84: 115-123$.

Bütikofer, U., J. Meyer, R. Sieber, B. Walther, and D. Wechsler. 2008. Occurrence of the angiotensin-converting enzyme-inhibiting tripeptides Val-Pro-Pro and Ile-Pro-Pro in different cheese varieties of Swiss origin. J. Dairy Sci. 91:29-38.

Cushman, D. W., H. S. Cheung, E. F. Sabo, and M. A. Ondetti. 1977. Design of potent competitive inhibitors of angiotensin-converting enzyme: Carboxyalkanoyl and mercaptoalkanoyl amino acids. Biochemistry 16:5484-5491.

Donkor, O. N., A. Henriksson, T. K. Singh, T. Vasiljevic, and N. P. Shaha. 2007. ACE-inhibitory activity of probiotic yoghurt. Int. Dairy J. 17:1321-1331.

FitzGerald, R. J., and H. Meisel. 2000. Milk protein-derived peptide inhibitors of angiotensin-I-converting enzyme. Br. J. Nutr. 84:S33-S37.

Gobbetti, M., P. Ferranti, E. Smacchi, F. Goffredi, and F. Addeo. 2000. Production of angiotensin-I-converting-enzyme-inhibitory peptides in fermented milks started by Lactobacillus delbrueckii ssp. bulgaricus SS1 and Lactococcus lactis ssp. cremoris FT4. Appl. Environ. Microbiol. 66:3898-3904.

Gobbetti, M., F. Minervini, and C.-G. Rizzello. 2004. Angiotensin I-converting-enzyme-inhibitory and antimicrobial bioactive peptides. Int. J. Dairy Technol. 57:173-188.

Gómez-Ruiz, J. A., M. Ramos, and I. Recio. 2002. Angiotensin-converting enzyme-inhibitory peptides in Manchego cheeses manufactured with different starter cultures. Int. Dairy J. 12:697-706.

Gómez-Ruiz, J. A., G. Taborda, L. Amigo, M. Ramos, and E. Molina. 2007. Sensory and mass spectrometric analysis of the peptidic fraction lower than one thousand Daltons in Manchego cheese. J Dairy Sci. 90:4966-4973.

Gómez-Ruiz, J. A., G. Taborda, L. Amigo, I. Recio, and M. Ramos. 2006. Identification of ACE-inhibitory peptides in different Spanish cheeses by tandem mass spectrometry. Eur. Food Res. Technol. 223:595-601.

Heber, E. M., L. Saavedra, and P. Ferranti. 2010. Bioactive peptides derived from casein and whey proteins. Bioactive peptides derived from casein and whey proteins. Pages 233-249 in Biotechnology of Lactic Acid Bacteria. F. Mozzi, R.R. Raya, and G. M. Vignolo, ed. Wiley-Blackwell, Ames, IA.

Korhonen, H., and A. Pihlanto. 2006. Bioactive peptides: Production and functionality. Int. Dairy J. 16:945-960.

Lopez-Fandiño, R., J. Otte, and J. Van Camp. 2006. Physiological, chemical and technological aspects of milk-protein-derived peptides with antihypertensive and ACE-inhibitory activity. Int. Dairy J. 16:1277-1293.

Muguerza, B., M. Ramos, E. Sánchez, M. A. Manso, M. Miguel, A. Aleixandre, M. A. Delgado, and I. Recio. 2006. Antihypertensive activity of milk fermented by Enterococcus faecalis strains isolated from raw milk. Int. Dairy J. 16:61-69.

Nakamura, Y., N. Yamamoto, K. Sakai, A. Okubo, S. Yamazaki, and T. Tacano. 1995. Purification and characterization of angiotensin I-converting enzyme inhibitors from sour milk. J. Dairy Sci. 78:777-783.

Ong, L., A. Henriksson, and N. P. Shah. 2007. Angiotensin converting enzyme-inhibitory activity in Cheddar cheeses made with the addition of probiotic Lactobacillus casei sp. Lait 87:149-165.

Ong, L., and N. P. Shah. 2008. Release and identification of angiotensin-converting enzyme-inhibitory peptides influenced by ripening temperatures and probiotic adjuncts in Cheddar cheeses. Lebenson. Wiss. Technol. 41:1555-1566.

Pihlanto, A., T. Virtanen, and H. Korhonen. 2010. Angiotensin I converting enzyme (ACE) inhibitory activity and antihypertensive effect of fermented milk. Int. Dairy J. 20:3-10.

Quirós, A., M. Ramos, B. Muguerza, M. A. Delgado, M. Miguel, A. Aleixandre, and I. Recio. 2007. Identification of novel antihypertensive peptides in milk fermented with Enterococcus faecalis. Int Dairy J. 17:33-41.

Renye, J. A., G. A. Somkuti, B. Vallejo-Cordoba, D. Van Hekken, and A. F. González-Córdova. 2008. Characterization of the microflora isolate from queso Fresco made from raw and pasteurized milk. J. Food Saf. 28:59-75.

Rodriguez-Figueroa, J. C., R. Reyes-Díaz, A. F. González-Cordoba, R. Troncoso-Rojas, I. Vargas-Arispuro, and B. Vallejo-Cordoba. 2010. Angiotensin-converting enzyme inhibitory activity of milk fermented by wild and industrial Lactococcus lactis strains. J. Dairy Sci. 93:5032-5038.

Saito, T., T. Nakamura, H. Kitazawa, Y. Kawai, and T. Itoh. 2000. Isolation and structural analysis of antihypertensive peptides that exist naturally in Gouda cheese. J. Dairy Sci. 83:1434-1440.

Seppo, L., T. Jauhiainen, T. Poussa, and R. Korpela. 2003. A fermented milk high in bioactive peptides has a blood pressure-lowering effect in hypertensive subjects. Am. J. Clin. Nutr. 77:326-330.

Sieber, R., U. Butikofer, C. Egger, R. Portmann, B. Walther, and D. Wechsler. 2009. ACE-inhibitory activity and ACE-inhibiting peptides in different cheese varieties. Dairy Sci. Technol. 90:47-73.

Silva, S. V., A. Phihlanto, and F. X. Malcata. 2006. Bioactive peptides in ovine and caprine cheeselike systems prepared with proteases from Cynara cardunculus. J. Dairy Sci. 89:3336-3344.

Swaisgood, H. E. 2003. Chemistry of the caseins. Pages 139-201 in Advanced Dairy Chemistry. Vol. 1: Proteins. Part A. 3rd ed. P. F. Fox, and P. L. H. McSweeney, ed. Kluwer Academic/Plenum Publishers, New York, NY.

Torres-Llanez, M. J., B. Vallejo-Cordoba, M. E. Díaz-Cinco, M. A. Mazorra-Manzano, and A. F. González-Córdova. 2006. Characterization of the natural microflora of artisanal Mexican Fresco cheese. Food Contr. 17:683-690.

Van Hekken, D. L., and N. Y. Farkye. 2003. Hispanic cheeses: The quest for queso. Food Technol. 57:32-38.

Whitworth. J. A. 2005. Blood pressure and control of cardiovascular risk. Vasc. Health Risk Manag. 1:257-260. 